\title{
МОДЕЛІ МЕХАНІЗМУ КОРПОРАТИВНОГО УПРАВЛІННЯ ДЕРЖАВНИМ СЕКТОРОМ ЕКОНОМІКИ
}

\author{
МОДЕЛИ МЕХАНИЗМА КОРПОРАТИВНОГО УПРАВЛЕНИЯ \\ ГОСУДАРСТВЕННЫМ СЕКТОРОМ
}

\section{MODELS MECHANISM OF CORPORATE GOVERNANCE PUBLIC SECTOR}

Досвід реалізачії механізму управління державними корпоративними правами в умовах ринкової економіки має свої особливості. В національних економіках наявне різноманітне поєднання державної власності, як базисної основи державного сектору економіки, і господарських суб'єктів ринку Узагальнення тендениій організації механізму управління корпоративними правами державного сектора дозволяє виявити інституційні складові його становлення, використання яких в національній економіці сприятиме забезпеченню ефективного управління державною власністю. Практики функиіонування економік розвинутих краӥн свідчить, щчо державний сектор є інструментом за допомогою якого держава виконує регулюючу функиію. Виходячи з изього припущення, розглянуто основні моделі механізму корпоративного управління державним сектором, які представляє практика світового господарства. Проаналізовано їх вплив на поведінку макроекономічних показників, структуру економіки за секторами, схильність до розвитку відповідних галузей на основі запровадження корпоративної моделі управління останніми. Визначено недоліки національного механізму корпоративного управління державним сектором та намічено напрями подальшого теоретичного $i$ практичного розвитку порушеного кола питань.

Ключові слова: моделі, механізм управління, корпоративні права, державний сектор.

Опыт реализации механизма управления государственными корпоративными правами в условиях рыночной экономики имеет свои особенности. В национальных экономиках имеется разнообразное сочетание государственной собственности, как базовой основы государственного сектора экономики, и хозяйственных субъектов рынка Обобщение тенденций организачии механизма управления корпоративными правами государственного сектора позволяет выявить институциональные составляющие его становления, использование которых в национальной экономике будет способствовать обеспечению эффективного управления государственной собственностью. Практики функиионирования экономик развитых стран свидетельствует, что государственный сектор является инструментом с помощью которого государство выполняет регулирующую функиию. Исходя из этого предположения, рассмотрены основные модели механизма корпоративного управления государственным сектором, которые представляет практика мирового хозяйства. Проанализировано их влияние на поведение макроэкономических показателей, структуру экономики по секторам, склонность к 
развитию соответствующих отраслей на основе внедрения корпоративной модели управления последними. Определень недостатки национального механизма корпоративного управления государственным сектором и намечень направления дальнейтего теоретического и практического развития нарушенного кругу вопросов.

Ключевые слова: модели, механизм управления, корпоративные права, государственный сектор.

Experience implementing mechanism for managing state corporate rights in a market economy is different. As national economies existing diverse mix of public property as basic foundations of the public sector and business entities market trends generalization mechanism of corporate governance of the public sector reveals the institutional component of its formation, the use of which in the national economy will promote effective management of state property. Practice of the economies of developed countries shows that the public sector is the tool by which the state performs a regulatory function. Based on this assumption, the basic model of corporate governance mechanism the public sector, which represents world-class economy. Analyzes their impact on the behavior of macroeconomic indicators, economic structure by sector, susceptibility to the development of relevant industries through the introduction of corporate management model last. Determined deficiencies of national corporate governance mechanism and planned public sector areas for further theoretical and practical development of impaired range of issues.

Keywords: model management mechanism, corporate law, the public sector

Вступ. У вітчизняній економічній науці питанням корпоративного управління наприкінці минулого століття почали приділяти помітну увагу. Це позв'язано з процесами трансформації економіки й об'єктивною необхідністю становлення нової системи відносин заснованої на принципах корпоративного управління. Зокрема, дослідженням правових проблем, пов'язаних 3 управлінням корпоративними правами займаються О.М.Каптуренко [6], О.В.Федькович [10]. Однак за цим напрямом, у реалізації українського законодавства відсутня однозначність теоретичних та практичних позицій, особливо відносно корпоративних прав держави. Щодо реалізації механізму корпоративного управління державою, то слід відмітити таких науковців Л.Є Довгань [4], Д.І. Погрібний [7] та інш., які зробили значний внесок у розвиток вітчизняних підходів до розуміння реалізації основних інструментів управління корпоративними правами держави. Разом 3 тим, потребує подальшого дослідження системність використання зазначених інструментів, що проявляють себе неоднозначно залежно від макро- та мікрочинників, які визначають відповідні моделі корпоративного управління.

Постановка завдання. Розглянути основні моделі механізму корпоративного управління державним сектором, проаналізувати їх вплив на розвиток економіки в цілому та за секторами у розрізі загальносвітових тенденцій і національної економіки.

Методологія. При розкриті суті предмету дослідження було використано структурний аналіз, що у поєднанні 3 загальнонауковими 
методами узагальнення та порівняння надав можливість охарактеризувати наявні моделі механізму корпоративного управління. Розкриття об'єкту дослідження здійснювалось за допомогою методів спостереження і графічного відображення.

Результати дослідження. При розгляді суб'єктивного права держави брати участь в управлінні товариства слід розрізняти зовнішню та внутрішню площини цього права, оскільки існують таки фактори впливу як політичні, економічні, соціальні тощо процеси. Звідси, зовнішня площина права держави брати участь в управлінні товариства проявляється через розробку корпоративного законодавства, а внутрішня - брати участь в управлінні товариства через міру іiі можливої поведінки як суб'єкта господарських відносин [7].

Державні корпоративні права реалізуються наявністю акціонерної власності в господарських товариствах. Зокрема, відповідно до «Рекомендацій ОССР 3 корпоративного управління у державних товариствах» (2005 року) термін «державне товариство» відноситься до товариств, в яких держава має значну участь у статутному фонді товариства через стовідсоткову, неконтрольну або значну частину у статутному капіталі товариства.

Так, в Австралії, Бельгії, Туреччині у всіх державних товариствах держава має майже стовідсоткову частку участі у статутних капіталах товариств. В Чехії, Швеції, Великій Британії майже три чверті акціонерних товариств підконтрольних державі, в Італії та Канаді до 70\% [2].

Найбільш розповсюдженою формою таких товариств $\epsilon$ закрите товариство та товариство з обмеженою відповідальністю, на них діють норми корпоративного законодавства. Але деякі країни, наприклад Чехія, управляють своїми державними товариствами відповідно до спеціального законодавства, або до законів, прийнятих спеціально для деяких державних товариств.

Кожна система корпоративного управління в різних країнах має свої відмінності, що дозволяє говорити про неї, як про окремі типи або моделі корпоративного управління [3]. На сьогодні можна виділити три основні моделі корпоративного управління: англо-американську, засновану на зовнішньому контролі, німецьку, орієнтовану на внутрішні механізми впливу та японську. Правове оформлення моделей корпоративного управління (правовий інструментарій) засновано на реальних економічних процесах, у тому числі глобалізаційних.

Як вже зазначалось вище, внутрішня площина суб'єктивного права держави брати участь в управлінні товариства проявляється через міру іiі можливої поведінки як суб'єкта господарських відносин. На нашу думку ця участь залежить не лише від правового аспекту а й від структури власності та складу ключових учасників корпоративних відносин. 
Так, корпораціями США та Великої Британії в цілому управляють зовнішні акціонери (аутсайдери). Тому не дивно, що в США створений ринок капіталу, а Лондонська біржа стала третьою по показнику капіталізації. Оскільки більшість громадян цих країн є акціонерами до того ж не одної корпорації, існують досить жорстокі правила розкриття інформації про діяльність корпорації.

Крім того, обов`язкове погодження акціонерів необхідно при виборі ради директорів та призначенні аудиторів корпорації. Але в США акціонери не мають права встановлювати розмір дивідендів. Рада директорів самостійно встановлює, скільки дивідендів виплачувати акціонерам на їх акції. У Великій Британії, навпаки, це питання відноситься до компетенції зборів акціонерів.

Оскільки кількість акціонерів, що не працюють в корпораціях, велика, всі зареєстровані акціонери отримують поштою повну інформацію про проведення зборів, річний звіт корпорації та бюлетень для голосування. При цьому підготовку загальних зборів та обробку його результатів здійснюють спеціальні консультаційні фірми [2].

Структура власності США, де основними власниками $є$ інституціональні інвестори, значно відрізняється від німецької моделі корпоративного управління. Основною відмінною рисою німецької моделі $\epsilon$ висока концентрація акціонерного капіталу [12, с.49]. Тому власники німецької моделі на відміну від власників англо-американської моделі мають можливість і зацікавлені у використанні права власника й особистій участі в контролі за менеджментом корпорації [11].

Японська система корпоративного управління має подібні риси 3 німецької, однак вона має й істотні відмінності. Хоча японська модель корпоративного управління формувалася після ІІ-ї Світової війни під впливом політики США, у той же час менталітет японської економіки, на нашу думку, вніс істотні корективи, і сьогодні японська система корпоративного управління, ми вважаємо, ближче до німецької, і має деякі відмінності від англо-американської.

Ключовими учасниками корпоративних відносин у Японії є головний банк (основний внутрішній акціонер), аффільована корпорація або кейрецу (ще один внутрішній власник), правління й уряд. Слід звернути увагу, що взаємодія між цими учасниками направлена на встановлення ділових контактів, а не на баланс, як в англо - американській моделі. В управлінні японськими корпораціями ключову роль відіграє державна економічна політика. Ця політика передбачає офіційне чи не офіційне представництво уряду в Раді корпорації, у випадках коли вона знаходиться у скрутному фінансовому стані.

Відповідно моделі корпоративного управління відрізняються структурою управління. Так, Рада директорів у США згідно правовим нормам 
- унітарна, до їі складу входять як менеджери, так і зовнішні директори. Між ними немає законодавчо розділених функцій у діяльності Ради Директорів, це питання залишається в компетенції власників корпорації.

В німецькій моделі корпоративного управління $є$ підбір членів виконавчої ради й у разі потреби їх звільнення. Крім цього, наглядова рада відповідає за затвердження балансового звіту, щорічного звіту корпорації, великих капіталовкладень, закриття виробництв і визначає рівень дивідендів. Серед співучасників у Радах директорів часто присутні уповноважені від банків, великих постачальників, рідше від груп споживачів і громадських організацій [12, С.85-87] . У великих підприємствах звичайно власники складають $30 \%$ Наглядової ради (всього 20 чоловік), інші співучасники - 20\%, за винятком службовців - 50\% місць [12, с.83] . Такий склад Наглядової ради, як основного інструменту контролю в рамках корпоративного управління, характеризує частку інвесторів, включених у систему корпоративного управління.

Таким чином, проведений нами аналіз діяльності Ради директорів німецької моделі дозволяють зробити припущення, що головним зобов'язанням системи представництв у Раді директорів є не захист інтересів якоїсь однієї групи інвесторів, а визнання загальної мети всіх співучасників корпорації, та підтримка конкурентоздатності корпорації.

На відміну від німецької моделі, в японській моделі у Раду директорів входять представники банків лише в кризових ситуаціях. Також у кризових ситуаціях уряд Японії уводить своїх повноважних представників і одночасно здійснює підтримку на шляху виходу з кризи. Ця модель корпоративного управління, як і німецька, характеризується високим відсотком банків у складі акціонерів компаній. При цьому думку суспільства в управлінні корпораціями підтримують «кейрецу», тобто групи компаній, об`єднаних спільним власником та управлінням. Насправді «кейрецу» - це мережа компаній, що характеризується спільним позичковим капіталом. Вони займаються торгівлею товарами та наданням послуг. Ця система корпоративного управління $є$ досить складною. У раді директорів корпорацій Японії обов`язково присутні офіційні та неофіційні представники уряду. При цьому японці вважають, що це дає можливість уряду вирішувати проблеми зайнятості населення. Більшість японців мають постійне місце роботи [2, c.13].

Основним елементом зовнішнього механізму корпоративного управління вищезазначених моделей $\epsilon$ корпоративний контроль. Його провідна роль в системі корпоративного управління в США пов'язана 3 впливом наступних факторів. По-перше, з найкращим розвитком фондового ринку США, що дозволяє вільно продавати власникам приналежні їм акції. По-друге, найбільшою розпорошеністю акції корпорацій США, що приводить 
до відсутності у власників багатьох корпорацій контрольного пакета акцій, достатнього для контролю за менеджментом корпорації.

У більшій частині німецьких корпорацій (особливо зі значно розпорошеним акціонерним капіталом) банки можуть цілком визначати склад наглядової ради (за винятком службовців) і блокувати будь-які рішення. Відсутність розвинутого ринку корпоративного контролю в німецькій моделі компенсується ефективним механізмом контролю з боку Ради директорів [12, c. 91].

Більшість німецьких корпорацій надає перевагу банківському фінансуванню (кредитуванню), а не акціонерному (емісія акцій). Тому i капіталізація фондового ринку Німеччини, на відміну від США, невелика. Банк одночасно виступає як акціонер корпорації і як ії кредитор. Він також виконує функції емітента цінних паперів та боргових зобов язань. Крім того, банк $є$ депозитарієм корпорації, а також голосуючим агентом на річних загальних зборах [2].

У японській моделі корпоративного управління акціонерні відносини базуються навколо ключового банку або фінансово-промислової групи. Банки $\epsilon$ основними утримувачами акцій корпорації. Банки надають своїм корпоративним клієнтам кредити та послуги по випуску облігацій, акцій, впровадженню розрахункових рахунків, а також консалтингові послуги.

Розглядаючи механізми контролю, необхідно відзначити, що в США банки не виконують тієї ролі в області контролю в рамках корпоративного управління, як у японській і німецькій моделях. Це пов'язано 3 тим, що антимонопольне законодавство США не дозволяє сполучати різні функції банків - кредитування (кредитні банки), випуск акцій і облігацій (інвестиційні банки), довірче управління акціями (спеціалізовані консалтингові компанії).

В англо-американській моделі найбільш важливими механізмами контролю за менеджерами, на нашу думку, є: формування грошової винагороди менеджерів та контроль з боку фондового ринку. В німецькій, та японській моделях найбільш повно знайшли відображення інтереси не тільки фінансових інвесторів: власників, банків, кредиторів і ін., але й не фінансових інвесторів: службовців, постачальників, громадських організацій.

Таким чином, функціонування системи управління корпоративною власністю в країнах з ринковою економікою, обумовлено існуванням різних моделей корпоративного управління. Проаналізовані моделі корпоративного управління, як ми уже відзначали, одержали своє поширення і за межами країн формування. Одним 3 факторів поширення тієї або іншої моделі корпоративного управління та реалізації корпоративних прав держави у світовій економіці $\epsilon$, на нашу думку, ступінь впливу країни на геополітичний порядок у світі. 
В наш час, в Європейському співтоваристві на державних господарських об'єктах зайнято більше 8 млн. чоловік, що складає майже 11 , 0\% всіх працюючих по найму. На них приходиться 12,5\% новоствореної власності та майже $20 \%$ валових капіталовкладень в основні фонди (окрім сільського господарства). Державні підприємства переважають в енергетиці (біля 70\% всіх зайнятих в цій галузі в Свропейському співтоваристві), транспорт і зв'язок (біля 60,0\% зайнятих); в фінансовому секторі (30,0\%). Також у Франції, Італії, Іспанії, Португалії, державний сектор має велике значення в таких галузях, як металургія, суднобуднобудування, машинобудування, хімія, харчова промисловість, атомна енергетика, дослідження космосу [13].

У багатьох країнах з ринковою економікою державним підприємствам, належить значна частка ВВП, зайнятості, ринкової капіталізації (див. табл.).

Таблиця

Частка державної власності в економіках країн СС у 1990 р. [5]

\begin{tabular}{|l|c|c|c|c|}
\hline \multicolumn{1}{|c|}{ Країни } & $\begin{array}{c}\text { У кількості } \\
\text { зайнятих, \% }\end{array}$ & У ВВП, \% & $\begin{array}{c}\text { У капітало- } \\
\text { вкладеннях, \% }\end{array}$ & $\begin{array}{c}\text { У середньому } \\
\text { по країні, \% }\end{array}$ \\
\hline Німеччина & 10,1 & 11,1 & 16,8 & 12,6 \\
\hline Італія & 15,0 & 20,0 & 26,0 & 20,3 \\
\hline Великобританія & 9,0 & 12,0 & 17,0 & 12,7 \\
\hline Франція & 17,6 & 19,5 & 34,9 & 24,0 \\
\hline Іспанія & 6,0 & 14,0 & 21,0 & 13,6 \\
\hline Голландія & 6,3 & 11,0 & 7,0 & 8,1 \\
\hline Бельгія & 11,0 & 8,3 & 14,0 & 11,1 \\
\hline Португалія & 12,1 & 21,0 & 35,0 & 22,7 \\
\hline Греція & 10,0 & 19,0 & 40,6 & 23,2 \\
\hline Данія & 8,2 & 6,0 & 20,0 & 11,4 \\
\hline Ірландія & 10,5 & 14,7 & 20,7 & 15,3 \\
\hline
\end{tabular}

Наприклад, у Китаї центральному урядові підпорядковано 17000 держпідприємств, а місцевим органам влади - $150 \quad 000 ; \quad 1200$ держпідприємств, зареєстровані на Шанхайській і Шеньчженьскій фондових біржах, де майже всі компанії з прямою або опосередкованою участю держави і на Гонконгській фондовій біржі, де китайські держпідприємства складають до $35 \%$ ринкової капіталізації, та створюють $18 \%$ ВВП і мають сукупну ринкову капіталізацію, рівну $40 \%$ ВВП.

В Індії в державному секторі 240 підприємств. Ці підприємства випускають 95\% вугілля, 66\% нафтопродуктів, 83\% природного газу, 32\% стали, $35 \%$ алюмінію і $27 \%$ всіх азотних добрив у країні. Понад однієї тисячі підприємств із державною участю налічується в колишніх соціалістичних країнах - Польщі і Чехії. У Греції, Іспанії, Німеччині й інших від 20 до 50 
державних підприємств. У Канаді, Франції, Великобританії, Австрії, Японії, Швеції і Фінляндії від 50 до 120.

Аналізуючи організацію регулювання державної власності, можна простежити відмінності відносно сфер діяльності, організаційно-правових форм державних підприємств, стану інституційного середовища. Сутність дій держави (за практикою західних держав) полягає в інвестуванні у галузі, що мають першорядне значення для розвитку суспільства. Наприклад, становлення і значний обсяг державної власності у французької економіці обумовлений необхідністю капіталовкладень для реалізації стратегічних великомасштабних проектів. Їх здійснення підштовхнуло до створення державних підприємств, які мали свою адміністративну раду і можливість розробки певних напрямків розвитку, а також отримання позик як від держави, так і від інших інвесторів («Поштове відомство», «Франс Телеком» та ін.) [14].

В умовах ринкової трансформації України, реформування відносин власності, представляє інтерес досвід зарубіжних країн, які пройшли етап активного адміністративного управління державним майном та сформували успішну, дієву економіку при наявності в ній частки державного сектора.

Таким чином, виникає потреба у створенні й впровадженні загальноєвропейських стандартів i правил, в Україні які б дозволили потенційним інвесторам, в т.ч. і іноземним, отримати повну, ясну й об'єктивну картину про ефективність діяльності компаній, реальних власниках, механізмах і методах інвестування, для того щоб у стислий термін i без значних витрат прийняти рішення про доцільність та надійність вкладення капіталу [6, С. 147-151]. Але, як зазначає Н.Г. Пронюк, що тут неможливе механічне перенесення положень правових актів в умови сучасної України" [8, с. 31].

Необхідно зазначити, при врахуванні зарубіжного досвіду управління державними товариствами та норм законодавства, потрібно усвідомлювати й особливості розвитку системи управління державними корпоративними правами в Україні та становлення корпоративного сектора в цілому.

Так, характерним випадком прояву трансформаційних впливів, які здійснювались на основі приватизаційних процесів була поява суб'єкти усіх форм власності: колективної (трудовий колектив підприємства, який має певний пакет акцій), приватної (зовнішні великі акціонери) і державної (у якості суб'єкта виступають власники державного пакета акцій). При цьому спостерігалось відчуження суб'єкта від однієї 3 функцій управління власністю, яке $\epsilon$ наслідком непогодженості в їхньому розподілі у тому числі і на рівні самих суб'єктів, що і призвело до наростання його відчуження від об'єкта власності. Це виразилось у віддаленні інтересів суб'єкта. Результатом загострення цих процесів стало зростання соціальної напруженості в трудових 
колективах, відтік інвестицій, недоотримання доходів державою від власності і розвиток інших негативних тенденцій. Зокрема зниження обсягів державного сектору зменшує поповнення бюджету, ускладнює виконання державою необхідних функцій і стримує стратегічний розвиток національної економіки. Навіть за умови, коли щорічно (після стрибка у 2005 р.) надходження дивідендів до бюджету країни перевищувало плановий обсяг, зокрема у кризові 2008-2010 рр. (рисунок). У 2012 р. обсяг дивідендів від господарської діяльності зріс на $46 \%$ порівняно з 2007 р., але це суттєво не вплинуло на інноваційно-інвестиційний розвиток вітчизняного виробництва, покращення добробуту населення і піднесення національного господарства в цілому.

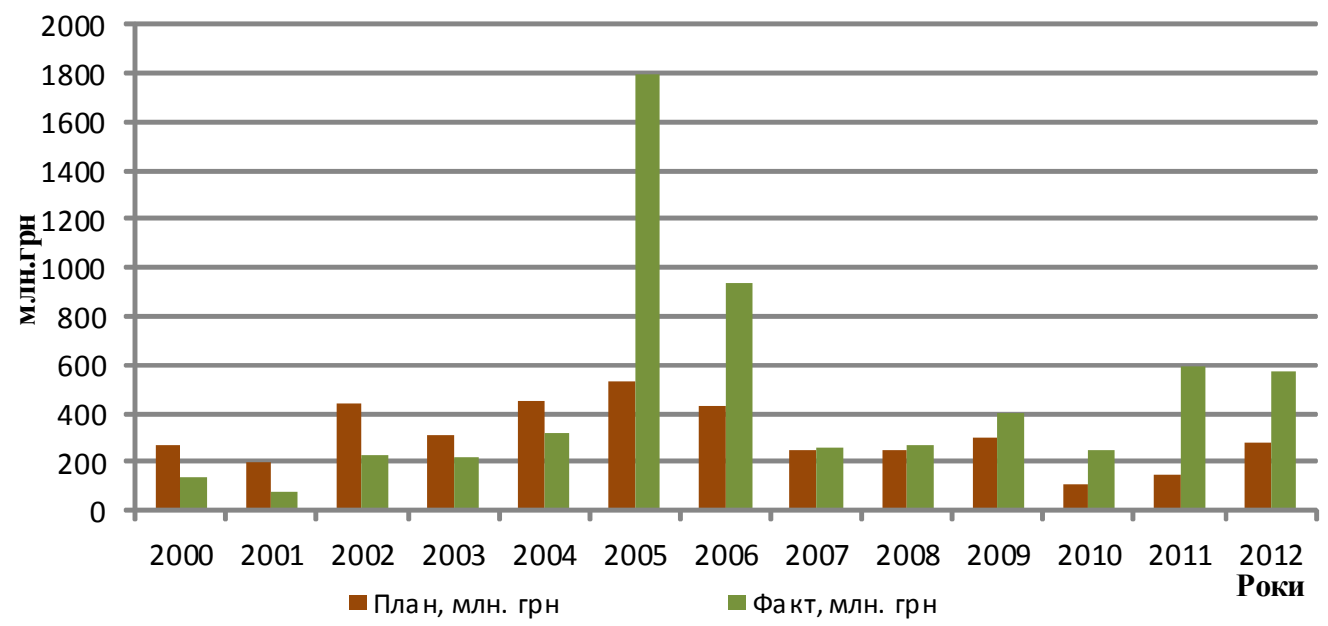

Рисунок. Надходження дивідендів до Держбюджету у 2000 - 2012 рp. [5] Примітка: ${ }^{1}$ - у тому числі 400238,0 тис. грн. - компенсація за отримані дивіденди на корпоративні права держави, стягнуті з ВАТ «Мітал Стіл Кривий Ріг» у зв’язку з продажем ВАТ «Криворіжсталь» в 2006 році.

Навпаки, використання наявної моделі механізму управління корпоративними правами держави відбувся значний відплив капіталу у вигляді прямих іноземних інвестицій. Наприклад, у 2007 р. (до початку фінансової кризи) в розмірі 6,0 млрд. дол, з якого майже $89 \%$ інвестицій здійснено підприємствами, зареєстрованими за видом економічної діяльності «операції з нерухомим майном, оренда, інжиніринг та надання послуг підприємцям». Закордонні прямі інвестиції з України були еквівалентні 76,2 \% приросту прямих іноземних інвестицій у 2007 р. Інвестування в певні сектори економіки $з$ високою ліквідністю та якнайшвидшим обігом коштів визначає пріоритетність інтересів інвесторів, що майже не сприяє структурному реформуванню економіки і модернізації ключових галузей промисловості (у зв'язку з відсутністю в них прямих іноземних інвестицій). Їх приріст у 2005-2008 рр. склав 26,7 млрд. дол. США, що майже втричі більше, ніж удалося залучити за весь період до 2005 р. Проте диспропорції у 
надходженні протягом цього періоду лише посилювалися, оскільки структура інвестицій має переважно фінансовий характер капіталу. Так, на посередницькі сфери діяльності в цей період припало майже 60,0\% загального приросту прямих іноземних інвестицій. Найбільш привабливими для іноземних інвесторів у 2005-2008 рр. виявилися фінансова діяльність, яка залучила 33,9 \% прямих іноземних інвестицій (6,5 млрд. дол. США), витрат на інноваційну діяльність, що становило лише 3,4 \% загального обсягу залучених ПІІ і 3,0 \% загального обсягу фінансування інноваційної діяльності [9, с. 323].

Вищезазначена тенденція майже не змінилася й нині. У 2012 р. іноземні інвестиції йдуть переважно у фінансову діяльність 29,57 \% (16,1 млрд. дол США), операції з нерухомим майном 16,63 \% (9, 1 млрд. дол США), торгівлю 11,02 \% (6,0 млрд. дол США). Позитивним зрушенням 2012 р. є збільшення інвестицій в промисловість - 31,52 \% (17,2 млрд. дол США) [1]. Також, слід зауважити, що вагому частину залучених інвестицій становили кошти від продажу низки великих об'єктів - ВАТ «Криворіжсталь», банків «Аваль» і «Укрсоцбанк». Іноземні інвестиції фактично зміцнювали сировинну, низькотехнологічну орієнтацію економіки України i спрямовувалися здебільшого на підтримку традиційних видів виробництв, наявною $\epsilon$ інноваційна непривабливість вітчизняних підприємств. Використання інвестицій, від яких насамперед залежить відтворення та модернізація національної економіки, залишається неефективним.

Висновки. Практичне значення отриманих результатів полягає в тому, що подальші завдання трансформації корпоративного механізму управління державним сектором України полягають у подоланні недоліків, які породжує відсутність інвестиційної активності зазначеного об'єкту на основі чіткого позиціонуванні держави щодо розвитку стратегічних галузей на основі даних специфічних організаційно правових формах господарювання. Також значення має те, що для будь якого об'єкту управління власник має бути персоніфікований. Це визначає способи впливу суб'єкта на об'єкт державного сектора. Особливо коли суб'єкти управління представляють макрорівень, оскільки держава, на відміну від інших власників, не завжди може керуватись при прийнятті рішення комерційними інтересами із-за соціально-економічної значущості об'єктів державного сектора та їх територіальної розшарованості.

Теоретичними надбаннями проведених досліджень $є$ те, що виявлено взаємозалежність наявності розвитку будь-якої із окреслених моделей корпоративного механізму управління державною власністю за умови, що існує виважена і системна політика уряду в умовах розмежування політичного i господарського управління країною. Подальший розвиток теоретичних i практичних розробок може бути сконцентрований на виявлення взаємозалежностей між використовуваними типами моделей та зміною довіри населення у перетвореннях відносин власності. 


\section{Література:}

1. Аналіз індексу інвестиційної привабливості в Україні [Електронний ресурс] // Інформаційно-аналітичний центр : [офіційний веб-сайт]. - Режим доступу: http://infolight.org.ua/ - Назва з титул. екрана

2. Баюра Д. Мировой опыт: корпоративное управление / Д.Баюра // Украинская Инвестиционная Газета. - 2000. - №43. - С.13

3. Городний В.И. Стратеггия формирования и развития крупной корпоративной компании: на примере ОАО «Татнефть» / В.И. Городний . - М.: Дело, 2005. - 304c. С.28

4. Довгань Л.С. Корпоративне управління: інституціональні аспекти : монографія.[текст] / Л.Є. Довгань, І.П. Малик / за ред. Л.Є. Довгань - К.: ІВЦ «Видавництво «Політехніка», 2006. $-340 \mathrm{c}$.

5. Звіт про роботу Фонду державного майна України та хід виконання Державної програми приватизації у 2012 році [Електронний ресурс] // Фонд державного майна України : [офіційний веб-сайт]. - Режим доступу: www.spfu.gov.ua/ukr/reports/spfu/2012_12.pdf.Назва з титул. екрана.

6. Каптуренко О.М. Щодо деяких проблем адаптації корпоративного законодавства України до законодавства ЄС / О.М. Каптуренко : Хозяйственное законодательство Украины : практика применения и перспективы развития в контексте европейского выбора: Сб.научн.тр. / НАН Украины. ин-т экономико-правовых исследований. - Донецк: ООО „Юго-Восток, Лтд”. - 2005. - С. 147-151.

7. Погрібний Д.І. Специфіка реалізації державою належних ій корпоративних прав / Д.І. Погрібний // Вісник Національного університету внутрішніх справ. - Х., 2005. - Вип. 31. - С. 318-321.

8. Пронюк Н.В. Проблеми впровадження європейських стандартів у законодавство України шляхом демократичних реформ / Н.В. Пронюк // Український часопис міжнародного права. - 2002. - № 4. - C. 31-36.

9. Україна в 2005-2009 рр.: стратегічні оцінки суспільно-політичного та соціальноекономічного розвитку / [О. К. Микал, С. І. Мітряєва, Н. І. Мхитарян та ін.] ; за ред. Ю. Г. Рубана. - К. : НІСД, 2009. -655 с.

10. Федькович О.В. Корпоративні права за законодавством України [Електронний ресурс] : Міністерство юстиції України / Режим доступу: http://www.minjust.gov.ua/18206

11. Храброва И.А. Корпоративное управление: вопросы интеграции. Аффилированные лица, организационное проектирование, интеграционная динамика./ Бона Фиде Финанс. М.: Изд. Дом «АЛЬПИНА», 2000. - 198 с.

12. Хессель M. Совет директоров корпорации: контроль через представительство. Корпоративное управление. Владельцы, директора и наемные рабочие акционерных обществ. - М.: Прогресс, 1992. - 420 c.

13. Швайка Л. А. Державне регулювання економіки : [підручник] / Л. А. Швайка. - К. : Знання, 2008. - $462 \mathrm{c}$.

14. WebKnow [Электронный pecypc] : веб-сайт / [Владелец сайта Долгов В. В.]. - Электрон. данные. - Херсон : [2012-2013] / - Режим доступа: www.webknow.ru. - Название с титул. экрана. 